\title{
Combined Hyperthermia and Radiation Therapy for Treatment of Hepatocellular Carcinoma
}

\author{
Roba M Talaat ${ }^{1 *}$, Tamer M Abo-Zeid ${ }^{1}$, Mahmoud T Abo-Elfadl ${ }^{2}$, Eman A \\ El-Maadawy ${ }^{1}$, Mona M Hassanin ${ }^{3}$
}

\begin{abstract}
Background: There is no doubt that hyperthermia is one of the powerful radiosensitizers. Finding a proper mechanism working in hyperthermia/radiation combination is still pronounced challenge. Objectives: This study is focusing on the anti-cancer activities (anti-proliferative, anti-angiogenic and antiapoptotic) of thermoradiotherapy. Materials and Methods: Liver cancer cell line (HepG2) was treated by $37^{\circ} \mathrm{C}, 40^{\circ} \mathrm{C}$ and $43^{\circ} \mathrm{C}$ hyperthermia degrees combined with three radiation doses (2 Gy, 4 Gy and 8 Gy) for 24, 48 and 72 hrs. Cell viability, apoptotic/necrotic cell screening, apoptotic (BAX and FasL) and antiapoptotic (BCL-2 and GRP78) genes, and pro-angiogenic mediators [vascular endothelial- $(V E G F)$ and Platelet derived-growth factors $(P D G F)$ ware investigated. Results: Our data showed that $40^{\circ} \mathrm{C}$ temperature combined with 4 Gy radiation gives a significant decrease $(\mathrm{p}<0.05)$ in cell viability. Maximum cytotoxicity was reported $48 \mathrm{hr}$ post-treatment followed by slight restoration of cell viability after $72 \mathrm{hr}$. Compared with untreated cells, only $5 \%$ of viable cells with a high percentage of apoptotic $(31 \%)$ and necrotic $(63 \%)$ cells were demonstrated in $40^{\circ} \mathrm{C} / 4 \mathrm{~Gy} / 48 \mathrm{hr}$ group. Expression of pro-apoptotic genes (BAX and $F a s L$ ) were increased after hyperthermia with apparent elevation in $40^{\circ} \mathrm{C} / 4 \mathrm{~Gy} / 48 \mathrm{hr}$ group coincides with moderate expression of antiapoptotic $B C L-2$ and $G R P 78$ genes. A significant reduction $(\mathrm{p}<0.001 ; \mathrm{p}<0.05)$ in $V E G F$ and $P D G F$ levels; respectively was shown at $40^{\circ} \mathrm{C} / 4 \mathrm{~Gy} / 48$ hr group. Conclusions: This pilot study proposed $40^{\circ} \mathrm{C}$ mild temperature hyperthermia as a favorable hyperthermal condition with 4 Gy radiotherapy in HCC treatment. A further research has to be performed considering an application of more than one session of radiothermal therapy at $40^{\circ} \mathrm{C} / 4$ Gy for total abrogation of cancer cells.
\end{abstract}

Keywords: Hyperthermia- radiotherapy- cytotoxicity- angiogenesis- apoptosis

Asian Pac J Cancer Prev, 20 (8), 2303-2310

\section{Introduction}

Primary liver cancer is one of the predominant malignancies and represents a major health problem in developing countries. More than $90 \%$ of cases are hepatocellular carcinoma (HCC) (El-Serag and Kanwal, 2014). HCC is the sixth most common cancer worldwide, being the fifth in men and the eighth in women. It accounts for approximately $5.7 \%$ of all new cancer cases. Annually, around $1 \%$ of all deaths in the world were related to HCC. Despite recent discoveries in screening strategies and novel therapeutic options, HCC is still the third leading cause of cancer mortality worldwide and remains one of the most difficult tumors to treat (Samonakis and Kouroumalis, 2017).

Hepatic resection and transplantation have been considered as the essential curative therapies for HCC. Unfortunately, most of patients were surgically unresectable due to tumor size, location, or underlying parenchymal disease (Llovet et al., 2015) Furthermore, the advanced neoplastic stage, severity of liver diseases or shortage lack of donors, restrict their application. For those cases, non-surgical therapies as chemotherapy and radiotherapy are recommended (Samonakis and Kouroumalis, 2017).

In the past few years, hyperthermia has been introduced as an effective approach for cancer therapy. The term 'hyperthermia' refers to several ways of heat application used as an adjuvant to establish strategy for cancer treatment such as radiotherapy and chemotherapy (Hildebrandt et al., 2002). With low side effects than chemotherapy and radiotherapy, adjuvant heat treatment has shown strong evidence in the management of tumors (Kampinga and Dikomey, 2001). Hyperthermia has been documented to have a killing effect on both normal and cancerous cells, even though; cancer cells are more sensitive to hyperthermia than normal ones (Kim et al., 2017). Efficacy of all hyperthermia modalities is not enough

\footnotetext{
${ }^{I}$ Department of Molecular Biology, Genetic Engineering and Biotechnology Research Institute (GEBRI), University of Sadat City, ${ }^{2}$ Cancer Biology and Genetics Laboratory, Center of Excellence for Advanced Sciences, National Research Center, ${ }^{3}$ Egyptian Atomic Energy Authority, Department of Radioisotope, Cairo, Egypt. *For Correspondence: roba.talaat@gebri.usc.edu.eg
} 
to replace any one of the established therapy modalities when applied alone, but, undoubtedly, they are suitable enough to enhance the cell-killing effect of cytotoxic drugs and/or radiation ('thermal chemosensitization', 'thermal radiosensitization') (Hildebrandt et al., 2002).

Several recent publications have focused on the effect of hyperthermia on distinct cellular signaling pathways, particularly of those involved in heat shock response, cell cycle regulation, and apoptosis. Moreover, hyperthermia influences tumor blood flow and oxygen/nutrient supply (Toraya-Brown and Fiering, 2014). Although there is a great number of researches on the therapeutic role of hyperthermia, there is little certainty about its effect on the process of angiogenesis (the sprouting of new capillaries from preexisting ones), which plays a vital role in tumor formation and maintenance (Bao et al., 2006). In the present study, we investigated the cytotoxic effect of combined therapy (thermal-radiosensitization) on HepG2 cancer cells and to clarify the role of this therapy on angiogenesis and apoptosis.

\section{Materials and Methods}

\section{Cell culture}

HepG2 cells were obtained from the American Type Culture Collection (ATCC) and were cultured at $37^{\circ} \mathrm{C}$ in RPMI-1640 medium supplemented with $10 \%$ fetal bovine serum (FBS), L-glutamine $(200 \mathrm{mM})$, penicillin $(100 \mathrm{U} / \mathrm{ml})$, streptomycin $(100 \mu \mathrm{g} / \mathrm{ml})$, and HEPES buffer (1M) (All from Biowest, Nuaillé, France). Cells were maintained in the logarithmic growth phase by routine sub culturing every 3-4 days in T75 tissue culture flasks. When reaching confluence, monolayer cells were rinsed with phosphate buffered slain (PBS) and harvested by trypsin/EDTA (Biowest) treatment. For the experiments, the cells were cultivated to $75 \%$ confluence on T25 tissue culture flasks.

Combined (Thermal/radiation) treatment of Hep 22 cells Hyperthermia was carried out for $30 \mathrm{~min}$ using 3 different incubators. After heating at $37^{\circ} \mathrm{C}, 40^{\circ} \mathrm{C}$ and $43^{\circ} \mathrm{C}$, flasks were irradiated by Cesium 137 radiation source in the Egyptian Atomic Energy Authority (EAEA), with dose rate of $0.00751 \mathrm{G} / \mathrm{sec}$. Thereafter, flasks were incubated for 24,48 and $72 \mathrm{hrs}$. Time interval between thermal and radiation therapy is $5 \mathrm{~min}$. Treated cells were grouped by temperature, radiation dose and length of incubation after treatment, generating $3 \times 3 \times 3=27$ groups. Each group is consisted of 3 flasks and named by Temperature $\left(37^{\circ} \mathrm{C}\right.$, $40^{\circ} \mathrm{C}$, or $\left.43^{\circ} \mathrm{C}\right) /$ Radiation dose $(2 \mathrm{G}, 4 \mathrm{G}$ and $8 \mathrm{G})$ and incubation period $(24,48$ and $72 \mathrm{hr})$ e.g. $37^{\circ} \mathrm{C} / 2 \mathrm{G} / 24 \mathrm{hr}$ group. Blank wells consisted of cells cultured alone with complete medium.

\section{Cytotoxicity assay}

Cell viability for all groups were measured by (3-(4,5-Dimethylthiazol)-2,5-Diphenyltetrazolium bromide) MTT assay as previously described (Talaat et al. 2014). Cell suspension $(200 \mu \mathrm{l})$ adjusted at $5 \times 10^{4}$ cells $/$ well were seeded in triplicates into flat-bottom 96- well tissue culture plates (Griener Labortechnik, Kremsmunster,
Austria). After removing the upper supernatant liquid (For VEGF and PDGF measurement), MTT solution $(5 \mathrm{mg} / \mathrm{ml})$ was added to each well $(40 \mu \mathrm{l} /$ well $)$ and incubated for $4 \mathrm{hr}$. Insoluble purple formazan crystals resulting from reduction of the yellow tetrazolium salt of MTT by mitochondrial dehydrogenases in metabolically active cells were dissolved by the addition of $160 \mu \mathrm{l} /$ well of acidified isopropanol $(0.04 \mathrm{~N} \mathrm{HCl}$ in absolute isopropanol) for $24 \mathrm{hr}$ at $37^{\circ} \mathrm{C}$. The absorbance at 570 nm was measured (FLUOstar OPTIMA; BMG Labtech $\mathrm{GmbH}$, Offenburg, Germany). The data are expressed as the mean percentage of viable cells as compared to the respective control cultures. The percentage of relative viability was calculated using the following equation: (Mean absorbance of treated cells/mean absorbance of control cells) X100.

\section{Apoptosis and necrosis staining}

The type of the cell death was investigated in all treated groups. Cells were examined for morphological features of apoptosis (chromatin condensation and fragmentation) and necrosis by fluorescence microscopy using acridine orange and ethidium bromide (AO/EB) uptake as described previously (Baskić et al., 2006; Mamoon et al., 2009 ). In brief, a mixture of $100 \mu \mathrm{g} / \mathrm{ml}$ acridine orange and $100 \mu \mathrm{g} / \mathrm{ml}$ ethidium bromide was prepared in distilled water. One microliter of dye mixture was mixed with $9 \mu \mathrm{l}$ of cell suspension and the cell uptake of the stain was monitored under a florescence microscope (Axio Imager. Z2, Carl Zeiss AS Kabelgaten Oslo Norge) using annexin $\mathrm{V} /$ propidium iodide versus acridin orange/ ethidium bromide and the apoptotic, necrotic and viable cells were counted. Treated cells were quantified by fluorescence microscopy according to the following descriptions: normal nuclei (bright green chromatin with organized structure), apoptotic (yellow chromatin that is highly condensed or fragmented), or necrotic (bright orange chromatin with round nuclei). The apoptotic index (percentage of apoptotic (or necrotic) cells) was calculated as number of apoptotic (or necrotic) cells/total cells counted.

\section{Detection of apoptosis by reverse transcriptase- polymerase chain reaction (RT-PCR)}

Total RNA from HepG cells was extracted with the TRIzol reagent, according to the manufacturer's instructions (Invitrogen, Carlsbad, CA, USA). Extracted RNAs were dissolved in RNase/DNase free water and quantified using a NanoDrop 2000c spectrophotometer (Thermo Fischer Scientific, USA). The isolated RNAs had an A260/A280 ratio of 1.6-1.8. To check the quality of extracted RNA, agarose gel electrophoresis was used. One microgram of RNA was reversely transcribed into cDNA followed by PCR using SuperScript ${ }^{\circledR}$ III One-Step RT-PCR System with Platinum ${ }^{\circledR}$ Taq DNA Polymerase (Thermo Fischer Scientific). BAX, BCL-2, GRP78, FasL and $\beta$-actin (Huang et al. 2011) were amplified by PCR with specific primer set (Table 1). Each cycle set used a denaturing temperature $\left(94^{\circ} \mathrm{C}\right)$ for $60 \mathrm{~s}$, annealing temperature $\left(55^{\circ} \mathrm{C}-58^{\circ} \mathrm{C}\right)$ for $90 \mathrm{~s}$, and extension temperature $\left(72^{\circ} \mathrm{C}\right)$ for $90 \mathrm{~s}$ for a total of 40 cycles for 
each primer, except $\beta$-actin where it was 30 cycles. The PCR products were separated on a $2 \%$ agarose gel containing ethidium bromide $(0.5 \mathrm{mg} / \mathrm{ml})$, visualized, and photographed using an 3UV Benchtop transilluminator Gel Documentation System supplied with DOC-IT (MSA) program (Ultra-Violet Products Ltd., UK). Relative intensity of the specific gene expression was analyzed by Image J software version 1.5J (NIH, Betheseda, MD, USA). mRNA expression was presented as expression index, the ratio of each signal to the signal from the $\beta$-actin housekeeping gene.

Determination of VEGF and PDGF by sandwich enzymelinked immunosorbent assay (ELISA)

Levels of VEGF and PDGF were quantified by ELISA using commercially available matched paired antibodies ( $\mathrm{R}$ and D Systems Inc., Minneapolis, MN) as previously described (Talaat et al. 2014). The intensity of the developed color was measured by reading optical absorbance at $450 \mathrm{~nm}$ using a microplate ELISA reader (FLUOstar OPTIMA). The ELISA reader-controlling software (softmax) calculates the data of raw absorbance value into a standard curve from which cytokine concentrations of unknown samples can be derived directly. Results were expressed as $\mathrm{ng} / \mathrm{ml}$. Duplicate measurements of each parameter were used to obtain the mean absorbance value.

\section{Statistical analysis}

Data were pooled from at least three independent experiments, and presented as mean with the corresponding SE. Differences between groups were analyzed using one-way analysis of variance. All the statistical analyses were performed with SPSS19.0 (SPSS, Inc., Chicago, IL). $\mathrm{P}<0.05$ was considered statistically significant.

\section{Results}

Effects of hyperthermia and radiotherapy on cell viability To monitor the potential effect of combined therapy on the tumor growth, initially we studied the cell viability at 24, 48 and $72 \mathrm{hrs}$ of HepG2 cells gathering treatment with radiotherapy $(2,4$ and $8 \mathrm{G})$ and hyperthermia $\left(37^{\circ} \mathrm{C}\right.$, $40^{\circ} \mathrm{C}$ and $43^{\circ} \mathrm{C}$ ) (Figure 1). We found that the $40^{\circ} \mathrm{C}$ temperature combined with $4 \mathrm{G}$ radiation displayed a significant decrease $(\mathrm{p}<0.05)$ in viability at different time intervals compared with untreated control group. Length of post-treatment incubation period was one of the most influential factors. Cell cytotoxicity was maximized after $48 \mathrm{hr}$ incubation time. A restoration of cell viability was notified after $72 \mathrm{hr}$ incubation period. Surprisingly, comparing different radiation doses revealed that $8 \mathrm{G}$ was the worst dose while $4 \mathrm{G}$ was the best. It appeared that the action of combined therapy was started after $24 \mathrm{hr}$, reaching maximum after $48 \mathrm{hr}$ and partially lost after $72 \mathrm{hr}$.

Effects of hyperthermia and radiotherapy on apoptosis and necrosis

To investigate whether the intact membrane of treated cells underwent apoptosis or not, we studied the type of cell death using acridine orange/ethidium bromide staining to distinguish between apoptotic, necrotic and viable cells. The counting indicated that $40^{\circ} \mathrm{C}$ temperature combined with $4 \mathrm{G}$ radiation evolved a significant reduction $(\mathrm{p}<0.05)$ in the percentage of viable cells $(5 \%)$ with high percentage of both apoptotic (31\%) and necrotic $(63.3 \%)$ ones (Figure 2).

\section{Effects of hyperthermia and radiotherapy on gene expression}

The effect of combined therapy on the expression of some pro- (BAX and FasL) and anti- (BCL-2 and GRP78) apoptotic genes was investigated. As shown in (Figure 3 ), the expression level of $B A X$ gene was varied. While an increase in $B A X$ expression with hyperthermia was observed in $2 \mathrm{G}$ and $4 \mathrm{G}$ treated groups after 24 and $48 \mathrm{hrs}$ with maximum production at $40^{\circ} \mathrm{C} / 4 \mathrm{G} / 48 \mathrm{hr}$, a reduction in $8 \mathrm{G}$ group was observed. Elevation in $8 \mathrm{G}$ group was restricted to normo-thermal ones. At the $72 \mathrm{hr}$, a severe reduction of $B A X$ expression in all tested groups was found. Concerning FasL results, elevation in FasL was detected in almost all tested groups. The highest level of FasL expression was shown at $37^{\circ} \mathrm{C} / 4 \mathrm{G} / 24 \mathrm{hr}, 40^{\circ} \mathrm{C} / 2 \mathrm{G} / 24$ $\mathrm{hr}, 40^{\circ} \mathrm{C} / 4 \mathrm{G} / 48 \mathrm{hr}, 43^{\circ} \mathrm{C} / 4 \mathrm{G} / 48 \mathrm{hr}$ and $43^{\circ} \mathrm{C} / 4 \mathrm{G} / 72 \mathrm{hr}$.

Gradual reduction in BCL-2 expression level was observed in $2 \mathrm{G}$ and $4 \mathrm{G}$ with various hyperthermia groups at different time intervals (Figure 4). There was a remarkable elevation in BCL-2 in cells treated with $8 \mathrm{G}$ after 24 and 48hrs. Severe reduction in BCL-2 was found in $40^{\circ} \mathrm{C} / 48 \mathrm{hr}$ for all radiotherapy doses $(2 \mathrm{G}, 4 \mathrm{G}$ and $8 \mathrm{G})$.

Table 1. List of Primers of Selected Apoptotic/Antiapoptotic Genes (Huang et al., 2011).

\begin{tabular}{llcc}
\hline Gene & Primers & Annealing & Product Size \\
\hline Bax & F: 5'-TCTGACGGCAACTTCAACTG-3' & $58^{\circ} \mathrm{C}$ & $188 \mathrm{bp}$ \\
& R: 5'-TTGAGGAGTCTCACCCAACC-3' & & $325 \mathrm{bp}$ \\
FasL & F: 5'-CTCTGGAATGGGAAGACACC-3' & $57^{\circ} \mathrm{C}$ & $203 \mathrm{bp}$ \\
Bc12 & R: 5'-ACCAGAGAGAGCTCAGATACG-3' & & $56^{\circ} \mathrm{C}$ \\
& F: 5'-TCCATGTCTTTGGACAACCA-3' & & $331 \mathrm{bp}$ \\
GRP78 & R: 5'-CTCCACCAGTGTTCCCATCT-3' & $56^{\circ} \mathrm{C}$ & $205 \mathrm{bp}$ \\
& F: 5'-GCTCTCGAATTCCAAAG-3' & & $55^{\circ} \mathrm{C}$ \\
\hline
\end{tabular}



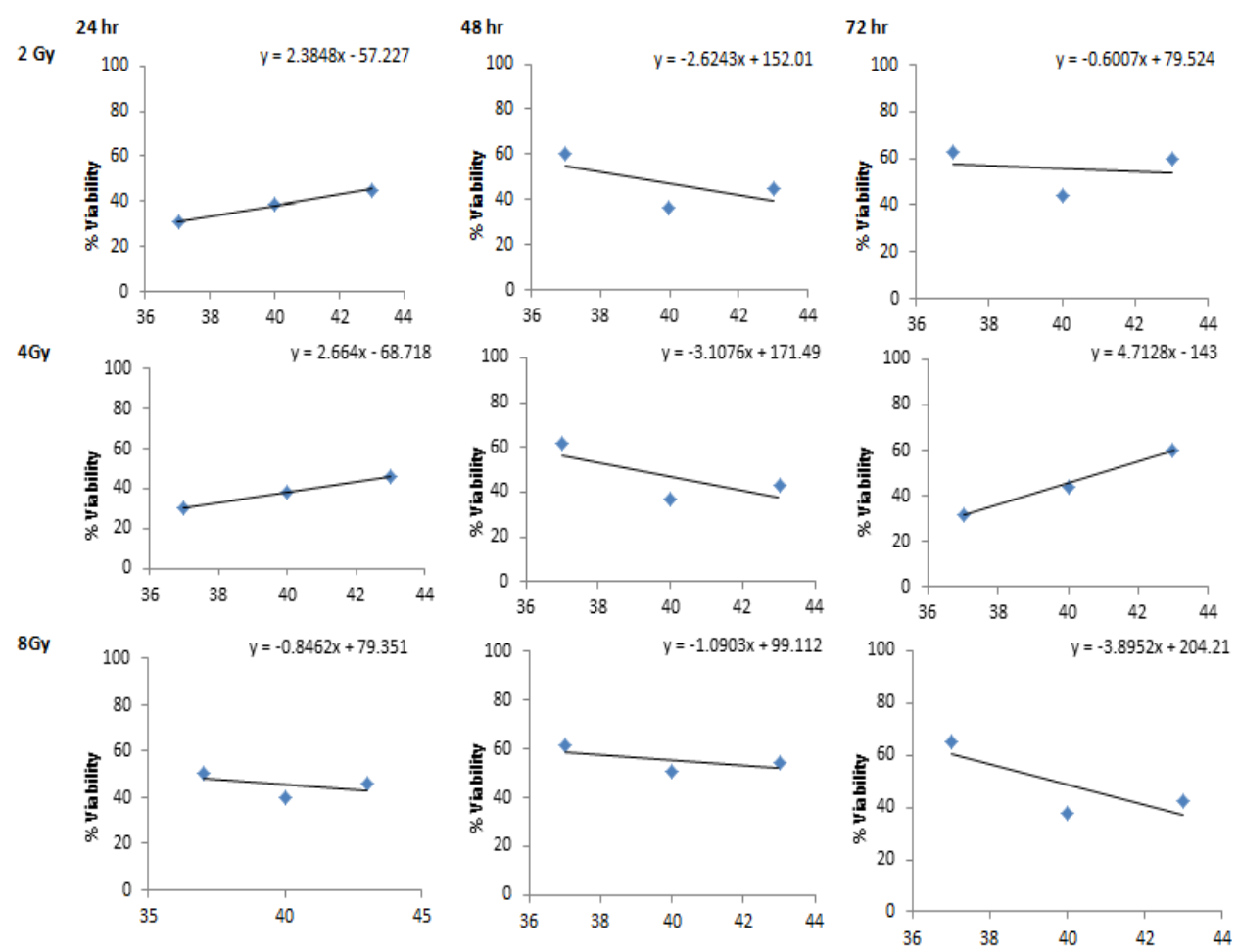

Figure 1. Cytotoxic Effect of Different Treated Groups on HepG2 Cells Using MTT Assay

Almost total abrogation of BCL-2 expression after $72 \mathrm{hr}$ at different groups of hyperthermia was observed in $4 \mathrm{G}$ and $8 \mathrm{G}$ groups. GRP78 expression level was increased in cells treated with $2 \mathrm{G}$ combined with $40^{\circ} \mathrm{C}$ at different time intervals followed by reduction in $43^{\circ} \mathrm{C}$ combinations. No change in GRP78 expression was observed in combination of $4 \mathrm{G} / 8 \mathrm{G}$ with different hyperthermia degrees at various time intervals with only one exception with $24 \mathrm{hr}$ which have very little amount of GRP78.

\section{Effects of hyperthermia and radiotherapy on pro-angiogenic factors}

As shown in Figure (5), insignificant change in VEGF levels at different hyperthermia time or radiation doses after $24 \mathrm{hr}$ incubation. A significant decrease $(p<0.001)$ in production of VEGF was observed after $48 \mathrm{hr}$ incubation in 2 treated groups; $43^{\circ} \mathrm{C} / 2 \mathrm{G}$ and $40^{\circ} \mathrm{C} / 4 \mathrm{G}$ as compared with normo-thermal group. In spite of temperature (37, 40 or $43^{\circ} \mathrm{C}$ ), $\mathrm{HCC}$ cells subjected to $8 \mathrm{G}$ radiation produced the highest/stable amount of VEGF. Of surprising, dramatic reduction in the levels of VEGF for all combined treated samples at $72 \mathrm{hr}$ post-treatment was observed.

At certain radiation dose $(2 \mathrm{G}$ and $4 \mathrm{G})$, the production of PDGF was significantly $(\mathrm{p}<0.05)$ reduced by hyperthermia in all groups after $24 \mathrm{hr}$ and $48 \mathrm{hr}$ incubation time in relation to normo-thermal group. As shown in

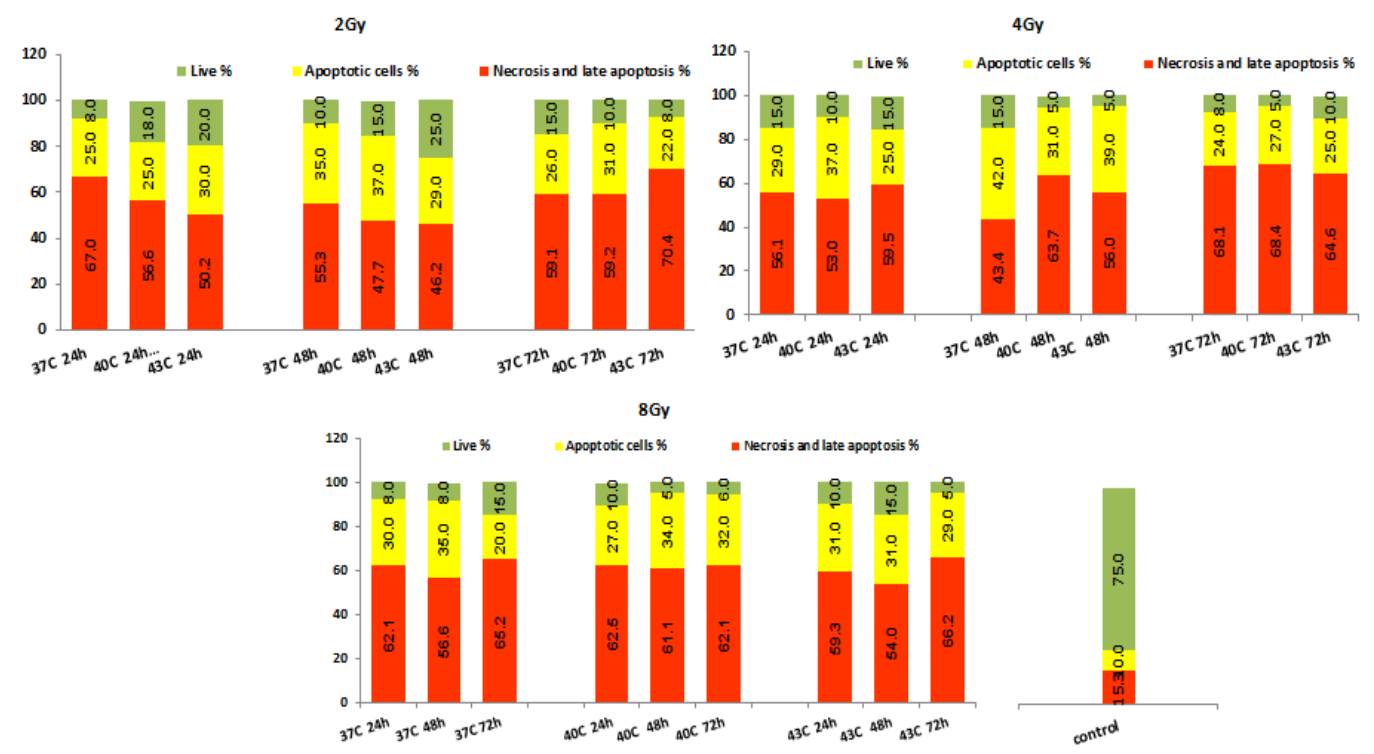

Figure 2. Comparison of the Number of Apoptotic/Necrotic Cells Scored by Fluorescence Microscopy Using Acridine Orange/Ethidium Bromide (AO/EB) in Different Treated Groups. 

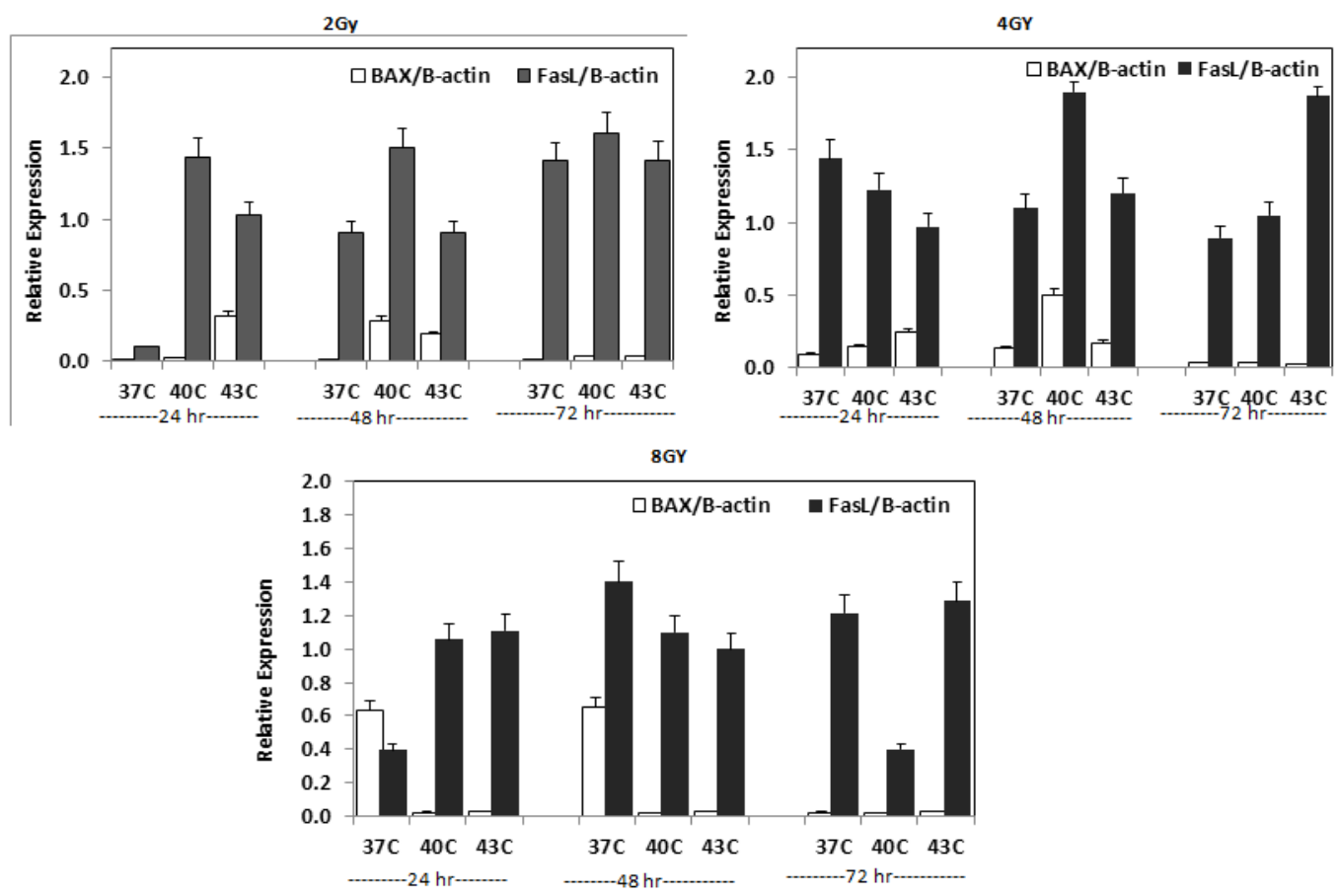

Figure 3. Apoptotic Gene Expression (BAX and FasL) in Different Treated Groups.

VEGF, the maximum reduction of PDGF was observed in $40^{\circ} \mathrm{C} / 4 \mathrm{G}$ group after $48 \mathrm{hr}$ incubation. Although, PDGF was almost abrogated in $40 \mathrm{oC} / 8 \mathrm{G}$ groups after $72 \mathrm{~h}$, no significant change was demonstrated in the rest of groups.

\section{Discussion}

The combination of hyperthermia with radiation has been discussed in several studies that show more achievement responses than radiation alone (Linchun et al., 2011; Dong and $\mathrm{Wu}, 2016$ ). These studies with many others before have positioned hyperthermia as the best radiosensitizer for treating tumors by radiation (Horsman and Overgaard ,2007). The clinical benefit of hyperthermia when combined with radiation has been proven in human trials for treatment of different types of malignancy including melanoma, glioblastoma, esophageal, head and neck, and cervix cancer (Chi et al., 2011). Regardless of these successes, the biologic rationale for combining hyperthermia with radiation is incompletely defined. Moreover, a significant variation in the response to hyperthermia between different types of cancers and/ or tumors of the same type was demonstrated (Vaupel and Kelleher, 2010). In this work we have addressed an
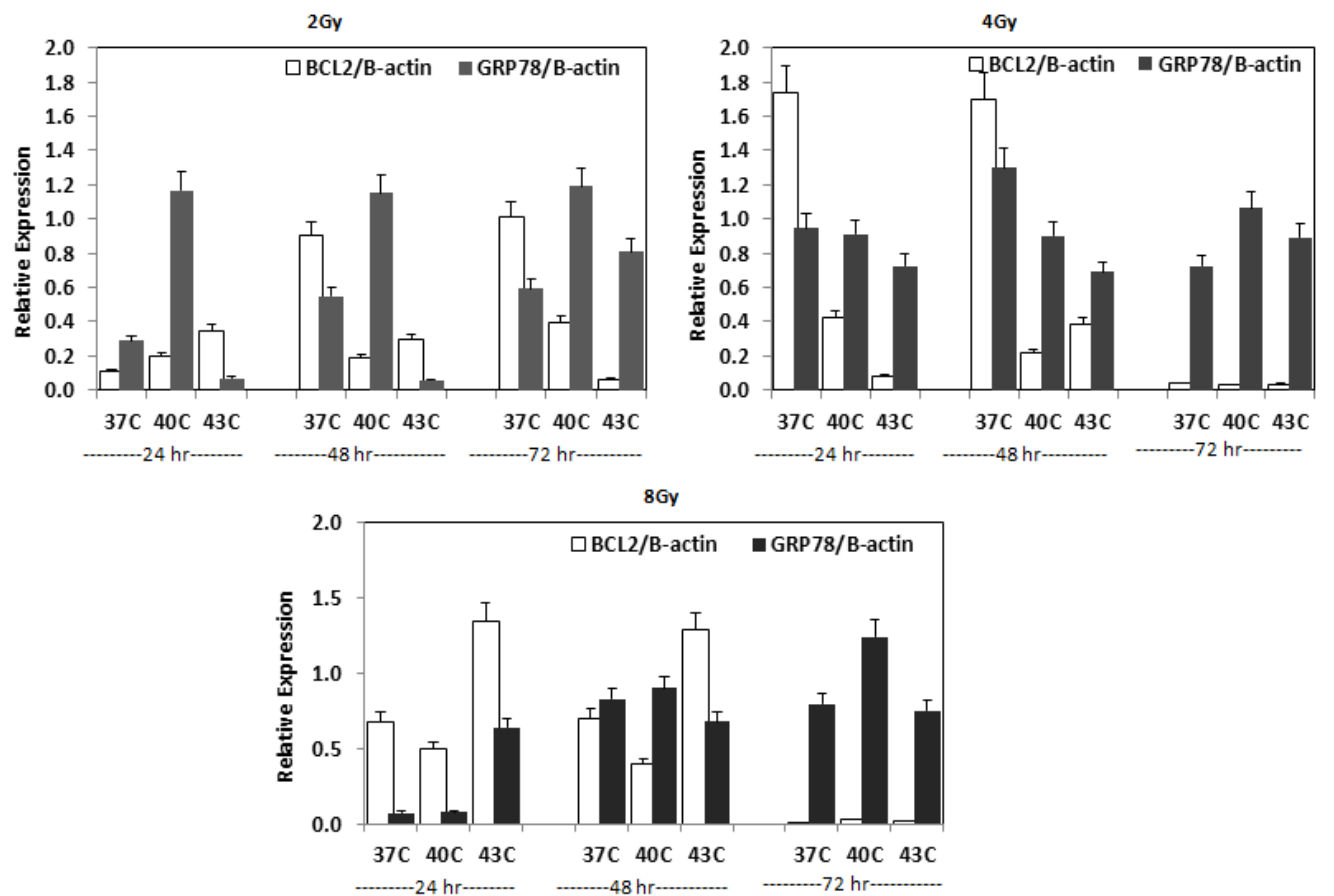

Figure 4. Anti-Apoptotic Gene Expression (BCL2 and GRP78) in the Different Treated Group 

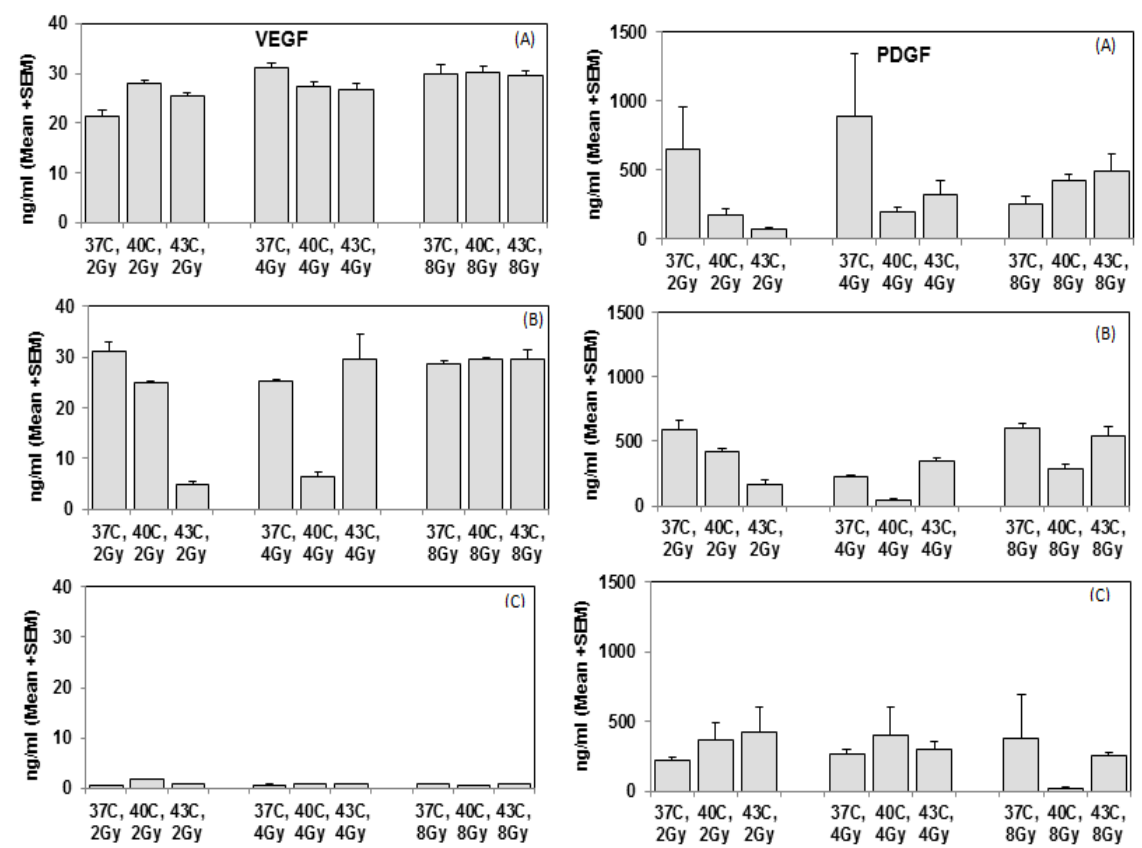

Figure 5. Level of VEGF and PDGF in Supernatant of Different Treated Groups. Results expressed as mean \pm SEM

important question about the cytotoxic activity of thermal radiosensitization in treating HCC cells and possible mechanisms involved through studying the effect of temperature and time on angiogenesis in combination with apoptotic/antiapoptotic gene interventions.

Our results showed that, although the cell viability surprisingly increased with radiation (from $30 \%$ at $2 \mathrm{G}$ to $50 \%$ at $8 \mathrm{G})$ in the normo-thermal groups $\left(37^{\circ} \mathrm{C}\right)$, the combined treated samples reported more stable results. The $40^{\circ} \mathrm{C}$ combined with $4 \mathrm{G}$ notably had the best results for cytotoxicity $(\sim=60 \%)$. There is strong proof that the potential of complete response and thus tumor control is increased by adjuvant heat treatment. Evidences indicate that hyperthermia interferes with the cells' ability to deal with DNA damage after radiation. Temperatures which is higher than $42^{\circ} \mathrm{C}-43^{\circ} \mathrm{C}$ kill tumor cells directly and indirectly (Griffin et al. 2010). On the other hand, although mild temperature hyperthermia (MTH) $\left(39^{\circ} \mathrm{C}-42^{\circ} \mathrm{C}\right)$ makes lower direct killing effects to tumors, it increases the cytotoxicity of radiation mainly by inhibiting the repairing mechanism of radiation-induced damage. This is consistent with our data where $40^{\circ} \mathrm{C}(\mathrm{MTH})$ has the maximum cytotoxicity effect. In vivo, the MTH; which also called the fever rang temperature; is effecting on immune-cells surrounding tumors that have an important role in cancer immunology (Takahashi et al., 2012). This appears clearly on natural killer (NK), dendritic and $\mathrm{T}$ cells, which increases its function at temperatures around $39^{\circ} \mathrm{C}-40^{\circ} \mathrm{C}$ and decline above that temperature (Ostbergi et al., 2003; Takahashi et al., 2012).

HCC tumors are highly vasculated, and the angiogenesis process is necessary for its development and progression (Tian et al. 2010). Among the angiogenesis factors, VEGF is the most important (Carmeliet, 2005) and its expression considered as a marker for $\mathrm{HCC}$ vasculation and metastasis (Kaseb et al., 2011). Following irradiation, angiogenesis and metastasis has been noted as an adverse effect of radiation treatment in many cancer cells (Wild-Bode et al., 2001; Qian et al., 2002; Rofstad et al., 2004), with an uncertain clarity in the HCC recurrence mechanisms after radiation, the VEGF was over expressed after that treatment (Chung et al., 2006). In our result, VEGF and PDGF were temporarily expressed after $24 \mathrm{hr}$ and $48 \mathrm{hr}$, before decline after $72 \mathrm{hr}$. The maximum reduction was notified after $48 \mathrm{hr}$ with $43^{\circ} \mathrm{C} / 2 \mathrm{G}$ and $40^{\circ} \mathrm{C} / 4 \mathrm{G}$ treatment for both parameters. The PDGF has shown a similarity in variation of protein levels with $V E G F$ which could indicate a common regulator in the HCC cells. Our findings of the relevance of change in expression of angiogenesis mediators are consistent with several other studies. The expressions of some genes associated with metastasis such as $V E G F$ was shown to be suppressed by heating (Sawaji et al., 2002; Liang et al., 2010). In a previous study, Yuan et al., (2012) found that hyperthermia can inhibit hypoxia- induced Epithelial-mesenchymal transition (EMT) in HepG2 HCC cells and suggested that hyperthermia may alter the metastatic potential of cancer cells and inhibit tumor metastasis. The immunocytochemical localization of VEGF in cytoplasm and cell membrane demonstrated that the expression of VEGF in cells treated with hyperthermia for 30 min was significantly reduced compared with the control group. In accordance with our results, they detected a reduction in the expression of VEGF mRNA by hyperthermia when temperature was above $43^{\circ} \mathrm{C}$ (Xie et al. 2011). In another study, Kim and his colleges have shown that applying $41^{\circ} \mathrm{C}$ for $30 \mathrm{~min}$. can reduce the radiation-induced upregulation of hypoxia inducing factor (HIF-1) and VEGF in FSaII fibrosarcoma inserted in legs of $\mathrm{C} 3 \mathrm{H}$ mice (Kim et al., 2017). In contrast, other previous results showed that both radiation (Moeller et al. 2004) and hyperthermia (Moon et al., 2010) increase HIF-1 levels, which drives VEGF signaling.

At the molecular level, it was reported that apoptosis 
is tightly regulated by caspases activation. Caspases can be activated through one of three pathways; extrinsic (or death receptor), intrinsic (mitochondrial) or endoplasmic reticulum (ER) pathways (O'Brien and Kirby, 2008; Huang et al., 2011). The extrinsic death receptor pathway is activated when death receptor of Fas (APO-1/ CD95) binds to its Fas ligand (FasL) resulted in receptor aggregation and recruitment of Fas associated death domain (FADD) (Hengartner, 2000). This recruitment leads to caspase- 8 activation which directly initiates apoptosis by cleavage of caspase-3 (Nagatar, 1997). The intrinsic pathway begins by targeting the mitochondrial permeability and cytochrome c release (Danial and Korsmeyer, 2004; Karpr, 2008). This pathway is regulated by $B C L-2$ family proteins which classified according to their role in apoptosis to pro-apoptotic (e.g. $B A X)$ and anti-apoptotic (e.g. $B C L-2)$ proteins. Apoptosis initiation or inhibition is directed by pro- /anti-apoptotic proteins balance (Kroemer et al., 2007; Huang et al., 2011) ER can trigger apoptosis through the activation of the unfolded protein response (UPR), ER-resident cysteine protease, caspase-12, leading to caspase-3 activation and apoptosis (Zhang et al., 2006; O'Brien and Kirby, 2008). Glucose-regulated protein (GRP78), also referred to as $\mathrm{BiP}$ (immunoglobulin heavy-chain binding protein), is an endoplasmic reticulum (ER)-resident chaperon protein responsible for protein folding and assembly. It has its roles in activation of transmembrane ER stress proteins and the degradation of misfolded proteins (Lee, 2007). GRP78 is bonded with many of malignancies and human cancer cell lines including HepG2 (Jamora et al., 1996; Fernandez et al., 2000; Tchounwou et al., 2001; Croute et al., 2002).

Hyperthermia can initiate apoptosis by affecting its known three pathways (Ahmed et al., 2015). In our results, both extrinsic (FasL) and intrinsic (BAX, BCL-2 and GRP78) pathways were investigated. Although the slight increase of $B C L-2$ with hyperthermia at $24 \mathrm{hr}, 2 \mathrm{G}$ group, the expression levels showing a decrease with hyperthermia at $4 \mathrm{G} / 24 \mathrm{hr}$ and $4 \mathrm{G} / 48 \mathrm{hr}$ groups. $40^{\circ} \mathrm{C}$ gives the lowest expression at $8 \mathrm{G} / 24 \mathrm{hr}$ and $8 \mathrm{G} / 48 \mathrm{hr}$. After 72 hr post-treatment, the combined treatment has strongly decreased the expression with hyperthermia. Thus, our results indicate that $B C L-2$ expression is down regulated by hyperthermia at $4 \mathrm{G}$ group in all three days. On the other hand, $B A X$ expression is upregulated with hyperthermia at $4 \mathrm{G}$ group. In consistent to our results, Pagliari et al., (2005) showed that heating cells to $43^{\circ} \mathrm{C}$ can directly activate $B A X$ and $B a k$ to permeabilize the mitochondrial outer membrane to release cytochrome c. Moreover, the study of Liang et al., (2007), on effect of hyperthermia on human colon cancer cell line (HT29), indicated that the expression levels of $B A X$ was up regulated with a contribution of down regulation in $B C L-2$ levels and this effect exceeded when combined with radiation and chemotherapy.

The results of FasL expression pointed that at $4 \mathrm{G}$, there was a slight decrease in FasL expression by hyperthermia, at $40{ }^{\circ} \mathrm{C}$ FasL was down regulated with high radiation doses at the three days. From these results, it seems that combination therapy affect the expression of FasL negatively. GRP78 expression pointed to a reduction in its level with hyperthermia and with radiation doses at 40oC. In agreement with our results, Xu et al., (2011) study indicated that GRP78 exhibited an induction in its expression level on $A D 293$ kidney cell line subjected to $40 \mathrm{oC}$ and decreased by hyperthermia at $43^{\circ} \mathrm{C}$.

In conclusion, our data focused on the importance of thermal-radio-sensitization as one of the effective anti-cancer therapy. We shed some light on $40^{\circ} \mathrm{C}$ mild temperature hyperthermia as the favorable hyperthermal condition with $4 \mathrm{G}$ radiation dose which affecting both angiogenesis and apoptosis processes. Our results stressed on the fact that the survived cancer cells after combined therapy can restore its efficiency and indicating to necessity for more than one therapy session. As delivering this fever range temperature to deep tumor malignancies as HCC is easy and applicable, this study may represent a major step in liver cancer treatment using radiothermal therapy.

\section{Acknowledgements}

\section{Funding}

This study was not funded by any grant from any agent.

\section{Ethical approval}

This article does not contain any studies with human participants or animals performed by any of the authors.

\section{Conflict of Interest Statement}

None of the authors have any conflict of interest regarding the chemical agents or topics discussed.

\section{References}

Ahmed K, Tabuchi Y, Kondo T (2015). Hyperthermia: an effective strategy to induce apoptosis in cancer Cells. Apoptosis, 20, 1411-9.

Bao S, Wu Q, Sathornsumetee S, et al (2006). Stem cell-like glioma cells promote tumor angiogenesis through vascular endothelial growth factor. Cancer Res, 66, 7843-8.

Baskić D, Popović S, Ristić P, Arsenijević NN (2006). Analysis of cyclohexamide-induced apoptosis in human leukocytes: Fluorescence microscopy using annexin V/propidium iodide versus acridin orange/ethidium bromide. Cell Biol Int, 30, 924-32.

Carmeliet P (2005). VEGF as a key mediator of angiogenesis in cancer. Oncology, 69, 4-10.

Chi JT, Thrall DE, Jiang C, et al (2011). Comparison of genomics and functional imaging from canine sarcomas treated with thermoradiotherapy predicts therapeutic response and identifies combination therapeutics. Clin Cancer Res, 17, 2549-60.

Chung YL, Jian JJ, Cheng SH, et al (2006). Sublethal irradiation induces vascular endothelial growth factor and promotes growth of hepatoma cells: Implications for radiotherapy of hepatocellular carcinoma. Clin Cancer Res, 12, 2706-15.

El-Serag HB, Kanwal F (2014). Epidemiology of hepatocellular carcinoma in the United States: where are we? Where do we go?. Hepatology, 60, 1767-75.

Griffin RJ, Dings RP, Jamshidi-Parsian A, Song CW (2010). Mild temperature hyperthermia and radiation therapy: role of tumor vascular thermotolerance and relevant physiological factors. Int J Hyperthermia, 26, 256-63.

Asian Pacific Journal of Cancer Prevention, Vol 20 
Hengartner MO (2000). Apoptosis: corralling the corpses. Cell, 104, 325-8.

Hildebrandt B, Wust P, Ahlers O, et al (2002). The cellular and molecular basis of hyperthermia. Crit Rev Oncol Hematol, 43, 33-56.

Horsman MR, Overgaard J (2007) Hyperthermia: a Potent enhancer of radiotherapy. Clin Oncol (R Coll Radiol), 19, 418-26.

Huang TT, Liu FG, Wei CF, et al (2011). Activation of multiple apoptotic pathways in human nasopharyngeal carcinoma cells by the prenylated isoflavone, osajin. PLoS One, 6, e18308.

Hwang SY, Heo K, Kim JS, et al (2015). Emodin attenuates radioresistance induced by hypoxia in $\mathrm{HepG} 2$ cells via the enhancement of PARP1 cleavage and inhibition of JMJD2B. Oncol Rep, 33, 1691-8

Jamora C, Dennert G, Lee AS (1996). Inhibition of tumor progression by suppression of stress protein GRP78/BiP induction in fibrosarcoma B/C10ME. Proc Natl Acad Sci US A, 93, 7690-4.

Kampinga HH, Dikomey E (2001). Hyperthermic radiosensitization: mode of action and clinical relevance. Int J Radiat Biol, 77, 399-408.

Karp G (2008). Cell and molecular biology: Concepts and experiments. 5 edition. John New Jersey: Wiley and Sons, pp 653-7.

Kaseb AO, Morris JS, Hassan MM, et al (2011). Clinical and prognostic implications of plasma insulin-like growth factor-1 and vascular endothelial growth factor in patients with hepatocellular carcinoma. J Clin Oncol, 29, 3892-9.

Kim W, Kim MS, Kim HJ, et al (2017). Role of HIF-1 $\alpha$ in response of tumors to a combination of hyperthermia and radiation in vivo. Int $J$ Hyperthermia, 28, 1-8.

Lee AS (2007). GRP78 induction in cancer: therapeutic and prognostic implications. Cancer Res, 67, 3496-9.

Liang H, Zhan HJ, Wang BG, Pan Y, Hao XS (2007). Change in expression of apoptosis genes after hyperthermia, chemotherapy and radiotherapy in human colon cancer transplanted into nude mice. World J Gastroenterol, 13, 4365-71.

Liang X, Zhou H, Liu X, et al (2010). Effect of local hyperthermia on lymphangiogenic factors VEGF-C and -D in a nude mouse xenograft model of tongue squamous cell carcinoma. Oral Oncol, 46, 111-5.

Linchun W, Chuanwen Y, Xiyan L, et al (2011) The analysis of efficacy of three dimensional conformal radiotherapy combined with radio frequency hyperthermia in the treatment of 42 patients with advanced hepatocellular carcinoma. J Basic Clin Oncol, 4, 311-3.

Llovet JM, Villanueva A, Lachenmayer A, Finn RS (2015). Advances in targeted therapies for hepatocellular carcinoma in the genomic era. Nat Rev Clin Oncol, 12, 408-24.

Mamoon A, Gamal-Eldeen AM, Ruppel ME, et al (2009). In vitro efficacy and mechanistic role of indocyanin green as photodynamic therapy agent - for human melanoma. Photodiagn Photodyn Ther, 6, 105116.

Moeller BJ, Cao Y, Li CY, Dewhirst MW (2004). Radiation activates HIF-1 to regulate vascular radiosensitivity in tumors: role of reoxygenation, free radicals, and stress granules. Cancer Cell, 5, 429-41.

Moon EJ, Sonveaux P, Porporato PE, et al (2010). NADPH oxidase-mediated reactive oxygen species production activates hypoxia-inducible factor-1 (HIF-1) via the ERK pathway after hyperthermia treatment. Proc Natl Acad Sci U S A, 107, 20477-82.

Nagata S (1997). Apoptosis by death factor. Cell, 88, 355-65.

O’Brien MA, Kirby R (2008). Apoptosis: a review of pro-apoptotic and antiapoptotic pathways and dysregulation in disease. $J$ Vet Emerg Crit Care, 18, 572-85.

Ostberg JR, Kabingu E, Repasky EA (2003). Thermal regulation of dendritic cell activation and migration from skin explants. Int $J$ Hyperthermia, 9, 520-33.

Pagliari LJ, Kuwana T, Bonzon C, et al (2005). The multidomain proapoptotic molecules $B A X$ and $B a k$ are directly activated by heat. Proc Natl Acad Sci U S A, 102, 17975-80.

Qian LW, Mizumoto K, Urashima T, et al (2002). Radiation induced increase in invasive potential of human pancreatic cancer cells and its blockade by a matrix metalloproteinase inhibitor, CGS27023. Clin Cancer Res, 8, 1223-7.

Samonakis DN, Kouroumalis EA(2017). Systemic treatment for hepatocellular carcinoma: Still unmet expectations. World J Hepatol, 9, 80-90.

Talaat R, El-Sayed W, Agwa H, et al (2014). Novel thalidomide analogs: Anti-angiogenic and apoptotic effects on Hep-G2 and MCF-7 cancer cell lines. Biomed Aging Pathol, http:// dx.doi.org/10.1016/j.biomag.2014.03.002.

Tian T, Nan KJ, Wang SH, et al (2010). PTEN regulates angiogenesis and VEGF expression through phosphatase-dependent and -independent mechanisms in HepG2 cells. Carcinogenesis, 31, 1211-9.

Toraya-Brown S, Fiering S (2014). Local tumour hyperthermia as immunotherapy for metastatic cancer. Int J Hyperthermia, 30, 531-9.

Vaupel PW, Kelleher DK (2010). Pathophysiological and vascular characteristics of tumours and their importance for hyperthermia: heterogeneity is the key issue. Int $J$ Hyperthermia, 26, 211-23.

Wild-Bode C, Weller M, Rimner A, et al (2001). Sublethal irradiation promotes migration and invasiveness of glioma cells: implications for RT of human glioblastoma. Cancer Res, 61, 2744-50.

Xie X, Shao X, Gao F, et al (2011). Effect of hyperthermia on invasion ability and TGF- $\beta 1$ expression of breast carcinoma MCF-7 cells. J Oncol Rep, 25, 1573-9.

Xu X, Gupta S, Hu W, McGrath BC, Cavener DR (2011). Hyperthermia induces the ER stress pathway. PLoS One, 6, e23740.

Yuan GJ, Li QW, Shan SL, et al (2012). Hyperthermia inhibits hypoxia-induced epithelial-mesenchymal transition in HepG2 hepatocellular carcinoma cells. World $J$ Gastroenterol, 18, 4781-6.

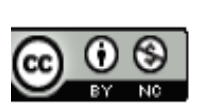

This work is licensed under a Creative Commons AttributionNon Commercial 4.0 International License. 